\title{
Time-space characterization of droughts in the São Francisco river catchment using the Standard Precipitation Index and continuous wavelet transform
}

\author{
Caracterização espaço-temporal de secas na bacia do rio São Francisco utilizando o Índice \\ Padronizado de Precipitação e a transformação contínua de ondaletas
}

\author{
Marcus Suassuna Santos ${ }^{1}$ (D), Veber Afonso Figueiredo Costa ${ }^{2}$ (D), Wilson dos Santos Fernandes ${ }^{2}$ (D) \\ and Rafael Pedrollo de Paes ${ }^{2,3}$ \\ ${ }^{1}$ Universidade de Brasília, Brasília, DF, Brasil \\ ${ }^{2}$ Universidade Federal de Minas Gerais, Belo Horizonte, MG, Brasil \\ ${ }^{3}$ Universidade Federal do Mato Grosso, Cuiabá, MT, Brasil \\ E-mails: msuassuna@gmail.com (MSS),veber@ehr.ufmg.br(VAFC),wilson@ehr.ufmg.br(WSF), rafaeldepaes@gmail.com (RPP)
}

Received: June 06, 2018 - Revised: February 28, 2019 - Accepted: April 14, 2019

\begin{abstract}
This paper focuses on time-space characterization of drought conditions in the São Francisco River catchment, on the basis of wavelet analysis of Standardized Precipitation Index (SPI) time series. In order to improve SPI estimation, the procedures for regional analysis with L-moments were employed for defining statistically homogeneous regions. The continuous wavelet transform was then utilized for extracting time-frequency information from the resulting SPI time series in a multiresolution framework and for investigating possible teleconnections of these signals with those obtained from samples of the large-scale climate indexes ENSO and PDO. The use of regional frequency analysis with L-moments resulted in improvements in the estimation of SPI time series. It was observed that by aggregating regional information more reliable estimates of low frequency rainfall amounts were obtained. The wavelet analysis of climate indexes suggests that the more extreme dry periods in the study area are observed when the cold phase of both ENSO and the PDO coincides. While not constituting a strict cause effect relationship, it was clear that the more extreme droughts are consistently observed in this situation. However, further investigation is necessary for identifying particularities in rainfall patterns that are not associated to large-scale climate anomalies.
\end{abstract}

Keywords: Droughts; Wavelet analysis; Standardized precipitation index; Climatic indexes.

\section{RESUMO}

Este artigo enfatiza a caracterização espaço-temporal de secas na bacia do rio São Francisco, com base na análise de ondaletas de séries temporais do Índice Padronizado de Precipitação (SPI). Para melhorar a estimação do SPI, os procedimentos para análise regional por momentos-L foram empregados na delimitação de regiões estatisticamente homogêneas. A transformada contínua de ondaletas foi utilizada para extrair informações da série temporal de SPI no plano tempo-frequência e para investigar possíveis teleconexões desses sinais com aqueles obtidos de amostras dos índices climáticos de larga escala ENSO e PDO. O uso de análise de frequência regional com momentos L resultou em melhorias na estimativa de séries temporais de SPI. Observou-se que, agregando informação regional, foram obtidas estimativas mais confiáveis de precipitação com baixa frequência de ocorrência. A análise de ondaleta dos índices climáticos sugere que os períodos secos mais extremos na área de estudo são observados quando a fase fria do ENSO e do PDO coincide. Embora não constituindo uma relação estrita de causa e efeito, ficou claro que as secas mais extremas são consistentemente observadas nessa situação. No entanto, é necessária uma investigação mais aprofundada para identificar as particularidades dos padrões de precipitação que não estão associados a anomalias climáticas em larga escala.

Palavras-chave: Secas; Análise de ondaletas; Índice padronizado de precipitação; Índices climáticos. 
Time-space characterization of droughts in the São Francisco river catchment using the

Standard Precipitation Index and continuous wavelet transform

\section{INTRODUCTION}

Droughts have been understood as natural disasters, which are triggered by abnormally low levels of precipitation during some prolonged time period. The shortage of rainfall affects a wide range of aspects related to water resources exploitation and management, encompassing water supply, irrigation and hydropower generation, among others. Drought conditions may jeopardize particular water uses, leading to potentially strong social, economic and/or environmental impacts. This fact, along with the increasing demands for water as a primary good for human and technological developments, has motivated a remarkable number of studies regarding drought conceptualization and forecasting in the last 50 years (e.g., MISHRA; SINGH, 2010, 2011 and references therein).

Difficulties for precisely defining droughts have been long noticed in the literature. A comprehensive review on this topic is presented by Sayers et al. (2016). Yevjevich (1967) suggests that the range of views on the concept of drought is a major obstacle for investigating the phenomenon. In effect, drought conditions summarize complex interactions between climatological and hydrological variables and, as a result, it is often unfeasible to pool all meaningful intervenient factors into a single mathematical formulation or index (MISHRA; SINGH, 2010). Accordingly, definitions of droughts are usually proposed within constraints related to their spatial extension, duration and the magnitude of their impact in water resources and human activities.

Several indexes have been utilized for characterizing drought conditions, such as the Palmer Drought Severity Index - PDSI, (PALMER, 1965), the Crop Moisture Index - CMI, (PALMER, 1968) and the Surface Water Supply Index - SWSI (SHAFER; DEZMAN, 1982). Although describing somewhat general drought conditions, most of these indexes are troubling for practical estimation, as they require the quantification of the available water content in several components of the water cycle besides the drought main driving process, i.e., precipitation. An increasingly utilized approach for estimating and forecasting meteorological drought conditions is the Standardized Precipitation Index (SPI), proposed by McKee, Doesken and Kleist (1993). SPI constitutes a simple probabilistic tool, whose estimation is solely based on aggregated precipitation amounts, and which is designed for evaluating how this quantity differs from normal conditions in a given area. SPI estimates may be thought as measures of standard deviations, with respect to the average rainfall condition, whose magnitude translate the drought severity. This provides easiness of computation and trivial interpretation to the referred drought index.

SPI has been widely employed in for assessing meteorological drought conditions, periodicity (SANTOS; PULIDO-CALVO; PORTELA, 2010; MOREIRA; MARTINS; PEREIRA, 2015) and mechanisms of propagation through the water cycle (BARKER et al., 2016). In fact, as it constitutes a standardized measure, SPI allows straightforward comparisons of cycles, duration and severity of drought events across regions subjected to distinct climatic characteristics (MISHRA; SINGH, 2010). In addition, as distinct time scales may be used for rainfall aggregation, insights on the catchments' lagged-responses to precipitation anomalies, which mainly depends on their hydrological and storage-related properties, can be readily obtained. (VAN LOON; LAAHA, 2015; BARKER et al., 2016).
Despite its simplicity, SPI, as any inference-based model, is deeply affect by the choice of the parent distribution and the available information content, as summarized by the number of sample points. As a means for improving statistical estimation, in this paper we propose performing the computation of the SPI time series within the regional frequency analysis with L-moments framework, as described by Hosking and Wallis (1997). Originally intended for hydrological information transfer, such an approach allows one to gather all available information across a region deemed statistically homogeneous for deriving dimensionless probabilistic models - the very concept of substituting time for space. The increase in the sample sizes, as obtained from regional analysis, should entail more reliable estimates of the parameters of probabilistic models (e.g., SADRI; BURN, 2011). In addition, besides improved statistical estimation, the partition of a given study area in homogeneous regions may provide a meaningful account on the drought spatial variability. This should be useful for identifying those locations more prone to water scarcity (SANTOS; PULIDO-CALVO; PORTELA, 2010; MOREIRA; MARTINS; PEREIRA, 2015) and for linking such spatial variation to large-scale and/or local climate driving processes (HUANG et al., 2017).

Reliably characterizing space-varying drought conditions via numerical indexes and statistical models is a major issue for water resources experts and planners. However, for obtaining a full picture on the drought behaviour, a more complete understanding of the temporal dynamics underlying such a phenomenon is often required. A common and increasingly utilized approach for aggregating additional information on droughts' time evolution is resorting to spectral analysis (TELESCA; VICENTE-SERRANO; LÓPEZ-MORENO, 2013; MOREIRA; MARTINS; PEREIRA, 2015; VAN HOEK et al., 2016). This class of methods is intended to express a time domain signal by means of its frequency components and their respective power. In this way, periodic or quasi-periodic associated properties of a physical process may be used for complementing the time series statistical analysis by revealing the dominating modes of oscillation.

Natural cycles of precipitation convey critical information on droughts frequency and on their links with exogenous forcing mechanisms (MOREIRA; MARTINS; PEREIRA, 2015). In fact, these cycles reflect the intra, annual and inter-annual time-space variability of climate patterns, which, at least to some extent, might explain the very distinct drought regimes usually found even in small regions. In general, for analysing SPI stationary signals, the Fourier transform is usually sufficient for providing a summary on the features of a given time series on the frequency domain (MOREIRA; MARTINS; PEREIRA, 2015). Nonetheless, due to the complexity of intervenient factors from which the onset and duration of droughts arise, SPI time series may exhibit non-stationary properties, which should limit the application of conventional spectral analysis tools. As an alternative, SPI time series may be explored using the Continuous Wavelet Transform (ZELEKE et al., 2017; ABDOURAHAMANE; ACAR, 2018).

Wavelet analysis has gained appeal in hydrological and climate sciences in the last two decades (TORRENCE; COMPO, 1998; LABAT; RONCHAIL; GUYOT, 2005; YANG et al., 2009; MASSEI et al., 2009, 2010), as it presents several advantages over traditional spectral estimation techniques, especially for allowing for time- frequency localization in a multiresolution analysis framework (LABAT, 2005). Under this perspective, particular features of a 
physical process, such as intermittent oscillation patterns and changes in periodicities, could be identified along with those cycles that occur in a regular basis. In addition, techniques such as wavelet cross analysis and wavelet coherence provide appropriate tools for assessing the joint variation of pairwise signals, which could be useful for uncovering cause-effect and phase relationships in physical processes (GRINSTED; MOORE; JEVREJEVA, 2004; ZELEKE et al., 2017).

In this paper, wavelet analysis is used in these contexts. The first part of the study aims at investigating the time evolution dynamics of drought conditions in the southern portion of the São Francisco River basin, located on the Brazilian south-eastern region. The main objective of this step is to identify periodic or nearly periodic patterns in SPI time series and to assess how drought cycles vary across the study area. Results from wavelet analysis may indicate those regions subject to shorter cycles, in which larger storage devices and special policies for drought protection may be required as a part of drought risk assessment and mitigation strategies (SANTOS; PULIDO-CALVO; PORTELA, 2010). In addition, the wavelet spectra may reveal time-varying patterns in the main modes of oscillation of SPI time series, which could provide some evidence of intensification or attenuation in the occurrence of drought events in the sites being studied.

The second part of the study is intended to detect teleconnections that drought events might present with large-scale climate phenomena, namely, the El Niño Southern Oscillation (ENSO) and the Pacific Decadal Oscillation (PDO), and to evaluate how such indexes affect the distinct homogeneous regions defined in the previous step. ENSO has been reported to influence precipitation anomalies and droughts in many parts of the world. In Brazil, its influence in the water cycle is more evident in the Northeast (e.g., MARENGO; TORRES; ALVES, 2017; CUNHA et al., 2018), Amazonian (LIMA; AGHAKOUCHAK, 2017) and Southern regions (FERNANDES; RODRIGUES, 2018). The links between PDO and rainfall patterns are also documented for these regions (KAYANO; ANDREOLI, 2004; STRECK et al., 2009). However, to the best of our knowledge, only a few initiatives on investigating the effects of these indexes on precipitation regimes have been attempted in the South-eastern and mid-western Brazilian states (BORGES; BERNHOFER;
RODRIGUES, 2018; OLIVEIRA-JUNIOR et al., 2018) and thus further investigation concerning such teleconnections is provided here.

The remainder of the paper is organized as follows: Section 2 contains an overview of the original SPI framework and a proposal for improving its estimation using regional frequency analysis with L-moments. A brief review of the Continuous Wavelet Transform is also presented in this section. Section 3 addresses an application of the method to time series of rainfall and SPI in the São Francisco River Basin. Finally, section 4 presents concluding remarks on the method and results thereof.

\section{THEORETICAL BACKGROUND}

\section{SPI estimation based on regional frequency analysis with L-moments}

This section comprises a brief overview of the SPI calculation process and describes an alternative approach for enhancing the SPI estimation by means of regional frequency analysis with L-moments, as suggested by Hosking and Wallis (1997). It is well established that L-moments estimators are more robust and usually more efficient as compared to the method of moments counterparts (NAGHETTINI, 2017). Therefore, by basing the inference on the former, the calculation of the SPI time series is likely to be less sensitive to the time series' lengths and to the presence of outliers. The SPI computation procedure is performed as follows. First, appropriate distribution functions, in terms of goodness-of-fit, are fitted to cumulative rainfall amounts, as aggregated in moving widows with fixed time span - usually 1, 3, 6, 9 and 12 months, with the use of the method of moments. Next, the non-exceedance probabilities, as associated to each observed record, are estimated from the cumulative distribution function. Then, the obtained non-exceedance probabilities are used for computing the corresponding quantiles of a standard normal distribution, which will constitute the SPI estimates for each duration. Figure 1 summarizes the outlined procedure. Some classes of droughts, based on SPI values, were

Normal distribution

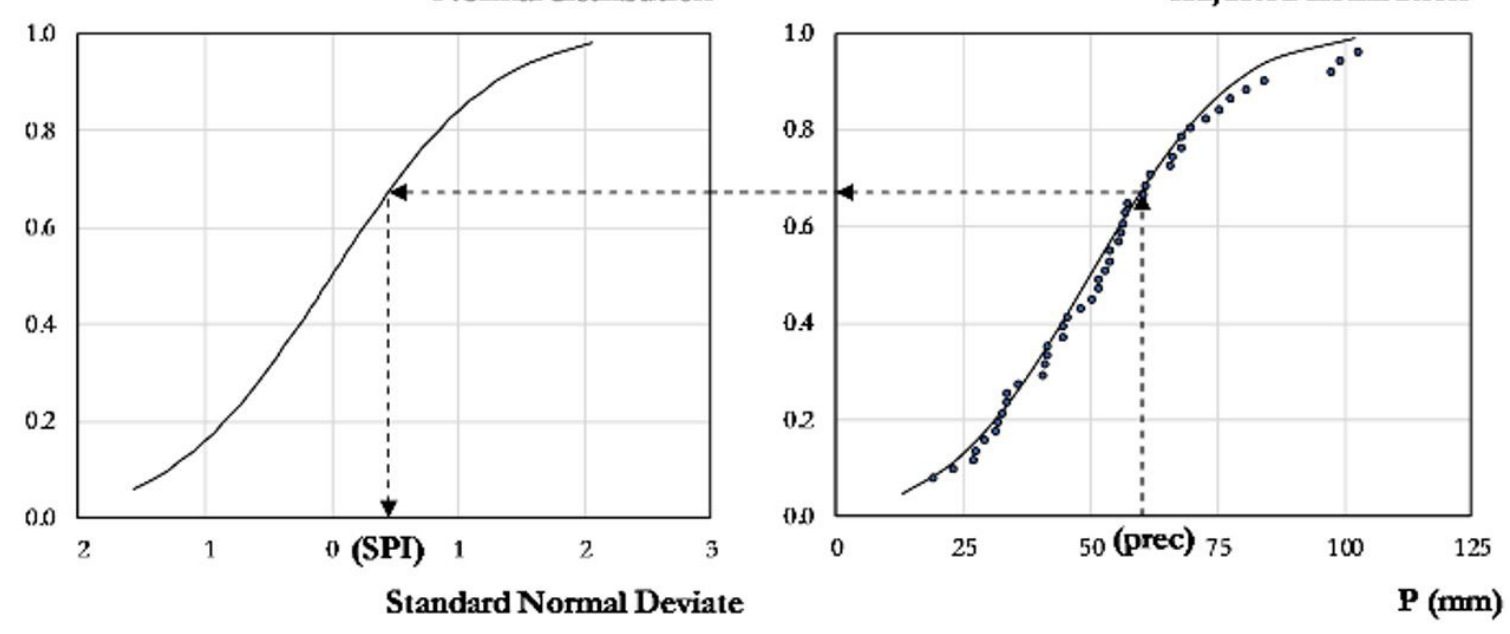

Figure 1. SPI calculation procedure. 
Time-space characterization of droughts in the São Francisco river catchment using the

Standard Precipitation Index and continuous wavelet transform

Table 1. Drought categories.

\begin{tabular}{ccc}
\hline Categories & SPI values & Time in class \\
\hline Extreme & $\leq-2.0$ & $2.28 \%$ \\
Severe & -1.99 to -1.50 & $4.40 \%$ \\
Moderate & -1.49 to -1.00 & $9.22 \%$ \\
Mild & -0.99 to 0.00 & $34.1 \%$ \\
\hline
\end{tabular}

Source: Adapted from McKee, Doesken and Kleist (1993).

defined by McKee, Doesken and Kleist (1993). Reference values are provided in Table 1.

Reliable estimation of the non-exceedance probabilities of aggregated rainfall amounts inherently depends on sample sizes and on the selection of the distributional model. Regarding the first issue, according to McKee, Doesken and Kleist (1993), time series with period-of-record longer than 30 years are required for statistical analysis. For practical applications, however, Guttman (1998) suggests that the samples must preferably contemplate more than 60 years, which is a relatively rare condition, particularly in developing countries. For circumventing this problem, in this paper we suggest increasing sample sizes by aggregating regional information in statistically homogeneous regions, following the method proposed by Hosking and Wallis (1997). The rationale behind this method is that, given a probabilistic model for the rainfall amounts and a normalizing index, each of these regions is described by a unique set of parameters, according to the scale invariance principle. The delimitation of homogeneous regions is based on heterogeneity measures. As for the dimensionless regional probability distributions, four models frequently used in hydrology were considered here, namely, the Generalized Logistic distribution, the Generalized Extreme Value distribution, the Generalized Normal distribution and the Pearson Type III distribution. These are models that encompass distinct decay behaviors in both lower and upper tails and should warrant that appropriate fits for aggregated rainfall random samples are obtained in all defined homogeneous regions.

\section{Wavelet Continuous Transform and wavelet coherence}

As mentioned before, the Continuous Wavelet Transform is an alternative to Fourier analysis for non-stationary signals. Wavelet functions, usually denoted by $\Psi$, are zero mean oscillating functions, localized in both frequency and time domains, which can be scaled by a factor $s$ and translated by a factor $u$, as shown in Equation 1.

$$
\Psi_{u, s}[x(t)]=\frac{1}{\sqrt{s}} \Psi\left(\frac{t-u}{s}\right)
$$

The Wavelet Transform of a certain signal, $x(t)$, can be defined as the convolution of $\mathrm{x}(\mathrm{t})$ with scaled and translated versions of $\Psi^{*}$, in which $\left(^{*}\right)$ indicates the complex conjugate of the wavelet function. The wavelet transform for a discrete signal $\mathrm{x}(\mathrm{t})$, with time step $\delta \mathrm{t}$, is given by:

$$
W_{n}(s)=\sum_{t=0}^{n-1} x_{t} \Psi^{*}\left[\frac{(t-u) \delta t}{s}\right]
$$

By resorting to Percival's (1995) equation, which indicates that an inner product in $\mathrm{L}^{2}(\mathrm{R})$ is preserved by the Fourier transform (up to a factor of $2 \pi$ ), the wavelet transform can be written as:

$$
W_{n}(s)=\sum_{k=0}^{n-1} \hat{x}_{t} \hat{\Psi}^{*} s \omega_{k} e^{i \omega_{k} n \delta t}
$$

where $\hat{x}_{t}$ and $\hat{\psi}^{*}$ are, respectively, the Fourier Transform of the signal $\mathrm{x}(\mathrm{t})$, at time $\mathrm{t}$, and of the complex conjugate of the wavelet function $\Psi$ at angular frequency $\omega_{k}$, which is expressed as:

$\omega_{k}=\frac{2 \pi k}{n \delta t}(-1)^{I_{(k>n / 2)}}$

where $\mathrm{k}=0, \ldots, \mathrm{n}-1$ is the Fourier frequency index and $l_{(.)}$is the indicator function. By using Equation 3 and a standard Fourier transform routine, it is possible to simultaneously and efficiently compute the continuous wavelet transform $W_{n}(s)$ for a given scale $s$, along the localized time index $n$ (TORRENCE; COMPO, 1998).

In this paper, following the recommendation of Grinsted, Moore and Jevrejeva (2004), we employed the Morlet wavelet function, as it provides a suitable balance between time and frequency resolutions. Such a wavelet function is given by

$\Psi(\eta)=\pi^{-1 / 4} e^{i \omega_{0} \eta} e^{-\eta / 2}$

where $\omega_{0}$ and $\eta$ are dimensionless frequency and time parameters, respectively.

By substituting $\left(\frac{t-u}{s}\right)$ for $\eta$ in Equation 5, the shifted and dilated form of the mother wavelet is given (TORRENCE; COMPO, 1998; LABAT, 2005). Following LABAT (2005), the Fourier transform of the Morlet wavelet function is given by

$\hat{\Psi}(\omega)=e^{-\left(\omega-\omega_{0}\right)^{2} / 2}$

Wavelet theory may also be used for evaluating potential co-oscillation relationships between signals. A common tool for this is the wavelet coherence, which is a normalized measure of time and scale for the relationship between two time series $\mathrm{x}(\mathrm{t})$ and $y(t)$ (SCHAEFLI et al., 2007). The wavelet squared coherency is defined as the absolute value squared of a smoothed crosswavelet spectrum, normalized by the smoothed wavelet power (TORRENCE; WEBSTER, 1999).

$$
W C O_{n}{ }^{2}(s)=\frac{\left|S \cdot\left[s^{-1} W C S_{n}^{X Y}(s)\right]\right|^{2}}{S\left[s^{-1}\left|W_{n}^{x}(s)\right|^{2}\right] \cdot S\left[s^{-1}\left|W_{n}^{y}(s)\right|^{2}\right]}
$$

in which $\operatorname{WCS}_{n}^{X Y}(s)$ is the product of the wavelet transform of the two signals. The factor " $\mathrm{s}$ " " is used to convert to an energy density and "S" is a smoothing operator related to wavelet scale axis and time separately (TORRENCE; WEBSTER, 1999; GRINSTED; MOORE; JEVREJEVA, 2004). The real part of $W C O^{2}$ represents the linear correlation between the signals at time $t$ and scale $s$ and the imaginary part denotes the phase between $x(t)$ and $y(t)$. 


\section{APPLICATION TO THE SÃO FRANCISCO RIVER CATCHMENT}

\section{Study area and dataset}

The São Francisco River is 2,700 km long, drains an area of about $640,000 \mathrm{~km}^{2}$, which encompass five Brazilian states, and has a population of nearly 14,000,000 inhabitants. The study area is, however, restricted to the state of Minas Gerais, which covers an area of $235,000 \mathrm{~km}^{2}$ and a population of around 7,000,000 inhabitants. This portion of the river is located between latitudes $14^{\circ} 13^{\prime} \mathrm{S}$ and $20^{\circ} 56^{\prime} \mathrm{S}$, and longitudes $42^{\circ} 30^{\prime} \mathrm{W}$ and $47^{\circ} 33^{\prime} \mathrm{W}$, as shown in Figure 2, and the catchment is characterized by intensive use of water resources and the presence of major cities.

A set of 124 rainfall gauging stations, encompassing periods-of-record of at least 25 years of data, was used for regional analysis. Monthly rainfall time series were obtained by aggregating daily precipitation amounts collected from Brazilian official database Hidroweb. Filling of missing data was performed by means of linear regression, using rainfall time series from nearby stations as predictors. It is worth mentioning that the gauging stations are not homogenously distributed, with a large concentration in the southeastern portion of study area, which is located in the vicinities of the metropolitan region of Belo Horizonte, and a lower concentration in the northern and northwestern regions of the State.

For entire set of rainfall gauging stations, hypothesis tests intended to assess randomness (NERC's turning points test), independence (Wald-Wolfowitz) and homogeneity (Mann-Whitney and Pettitt) were conducted (NAGHETTINI, 2017). The tests were performed considering rainfall aggregation in annual basis and at the significance level of 5\%. For a few gauging stations, the null hypothesis of independence was rejected. In the context of our paper, however, such a lack of serial independence should not strongly affect the delimitation of homogeneous regions. In effect, the resulting information content, materialized by the total number of sample points in each of these regions, is likely to be large, which tends to lessen the bias in the regional L-moment estimates.

As for the homogeneity tests, 9 stations were deemed inhomogeneous by the Mann-Whitney test, most of them in the

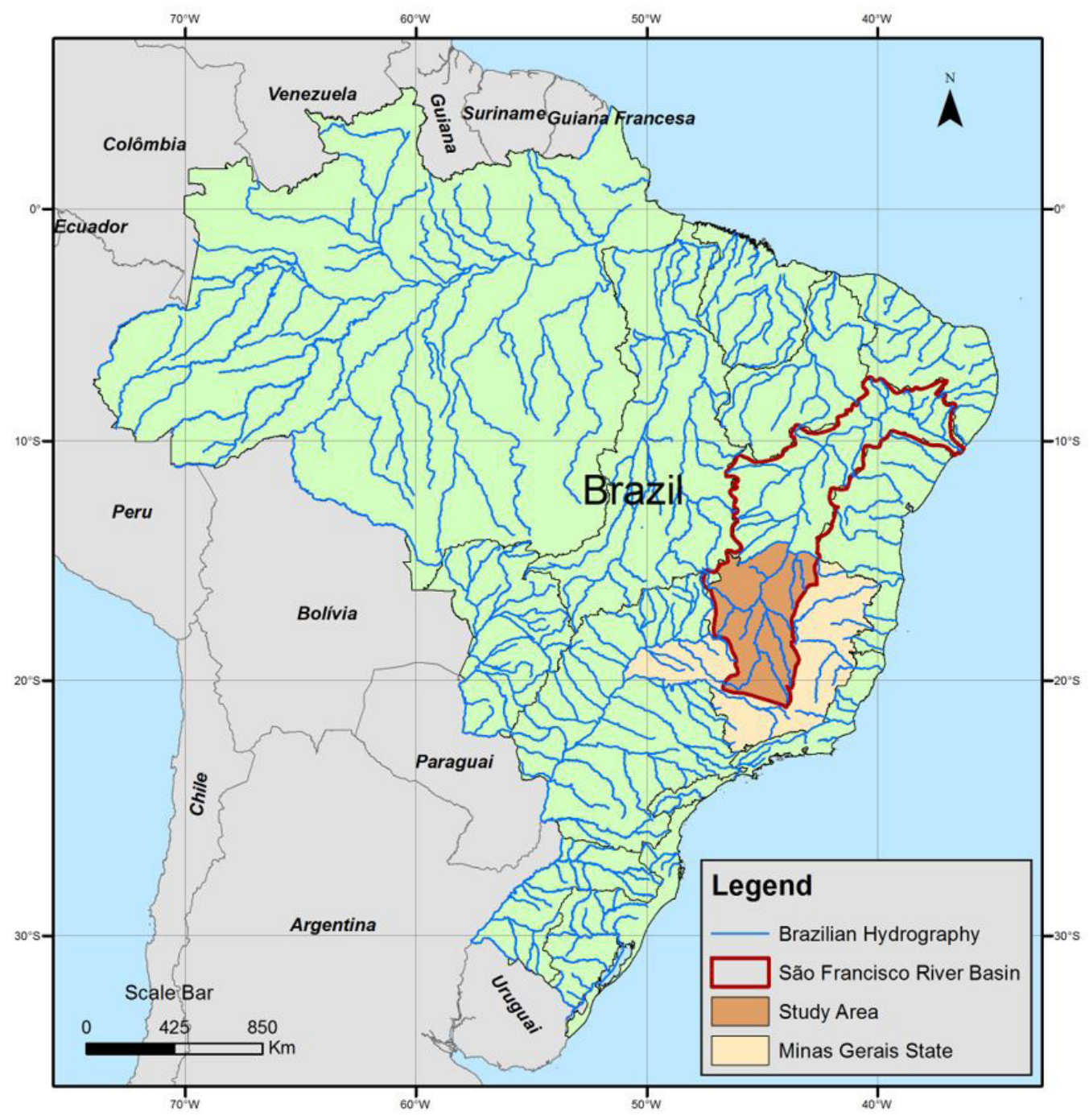

Figure 2. The San Francisco River Basin and its situation. The study area is highlighted in brown. 
Time-space characterization of droughts in the São Francisco river catchment using the

Standard Precipitation Index and continuous wavelet transform

northern portion of the study area. For the Pettitt counterpart, the null hypothesis was rejected for 4 stations, with 2 of them located in the referred part of the catchment. Nonetheless, as the rainfall gauging station network is sparse in this area, and this fact may entail very large homogeneous regions, not necessarily governed by the scale invariance principle, we decided not to remove such stations from the analysis.

In addition to rainfall data, large-scale climate indexes information was used for investigating teleconnections. Records of ENSO intensity, spanning from 1950 to 2006, are available in CPC (2019). On the other hand, PDO data, whose period-of-record contemplates the years between 1900 and 2011, was obtained in JISAO (2019).

\section{Definition of hydrological homogeneous regions and regional probability distribution functions}

The application of Hosking and Wallis' routines for regional analysis, comprising discordance and heterogeneity measures, resulted in 10 distinct homogeneous regions, each one of them associated to a specific dimensionless regional frequency distribution. Such regions are shown in Figure 3. It is possible to note that homogeneous regions further south (especially regions 7 to 10) are smaller than the others, whereas the regions further north are significantly larger (especially regions 1 to 4 ). We believe that the reason for this difference is associated, to some extent, to the total rainfall amounts observed in these regions. The northern regions have semi-arid characteristics, whereas the southern regions are relatively wet. It is also possible that the distinct terrain topographic characteristics have some impact in this difference, since the southern regions had to be subdivided progressively until the final configurations matched the criteria of homogeneity and

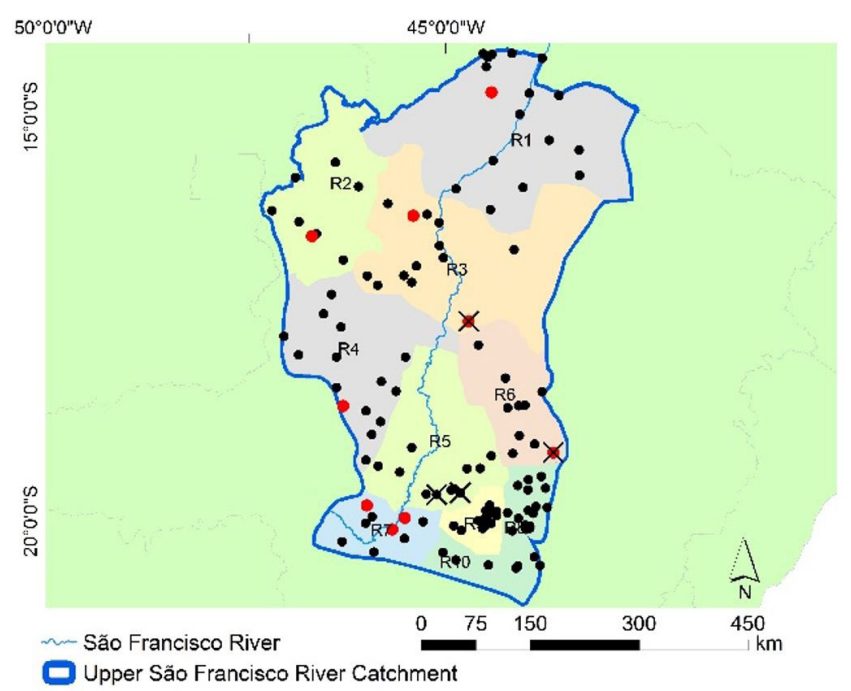

Figure 3. Hydrological homogeneous regions. Black dots denote stations not rejected in the Mann-Whitney and Pettitt tests. Red dots indicate stations rejected in the Mann-Whitney test. Black crosses indicate stations rejected in the Pettitt test. a unique regional probability distribution could be fitted to each homogeneous region.

The dimensionless regional probability distributions were selected on the basis of the L-ratio diagrams and the goodness-of-fit measure proposed by Hosking and Wallis (1997). Although the Generalized Extreme Value distribution and the Pearson Type III distribution be generally utilized the for modeling of block-maxima, in this study they were used to model the entire random sample, including minimum, mean and maximum values. No further issues with their use are expected, since these distributions provided appropriate fits for samples comprising the entire spectrum of rainfall amounts.

An expeditious comparison was performed between SPI time series obtained with the original methodology, as described by McKee, Doesken and Kleist (1993), and those estimated with the regional analysis with L-moments. Such a comparison revealed that, although the most common rainfall volumes were associated to similar SPI values, those precipitation amounts with lower exceedance probabilities can be considerably distorted. The largest distortions were noticed in regions 01,06 and 07 , as shown in Figure 4. Such differences may be related to unsuitable descriptions of the rainfall distribution upper tails when the Gamma model is utilized for SPI computation (see KATZ; PARLANGE; NAVEAU, 2002; PAPALEXIOU; KOUTSOYIANNIS, 2016; COSTA; FERNANDES, 2017, for details on the upper tails of environmental random variables), and, at least to some extent, to more reliable parameter estimates obtained by means of the regional models, which also improves the estimation of the non-exceedance probabilities of aggregated rainfall amounts.

\section{Wavelet analysis of SPI time series}

For the analyses in this paper, we utilized the 9-month SPI. This choice was based on the rainfall average behavior in the study area. In fact, almost all observed rainfall occurs from October to April and, thus, the 9-month scale is appropriate for encompassing this entire period. After estimating SPI values, the resulting time series were subjected to time-frequency multiresolution analysis. The estimation of wavelet power spectra and the significance tests were carried out with $\mathrm{R}$ routines developed by Gouhier, Grinsted and Simko (2018). As an example, details on timefrequency domain information provided by wavelet analysis in region 01 is shown in Figure 5. Statistically significant cycles of 16 years were identified, designating 1970 as the core year, within the cone of influence. Cycles of 2 to 4 years are verified between 1940 and 1960, and these cycles apparently become larger from the latter until the early 1990's. For practical purposes, the very possibility of evaluating such kind of changes in periodicity along the period of record may constitute an advantage of wavelets over traditional spectrum analyses techniques (see for instance, SANTOS; PULIDO-CALVO; PORTELA, 2010).

Wavelet analysis results in other homogeneous regions are shown in Figure 6. 16-year cycles are observed in the Southern, western and northern regions of the study area. Such cycles, however, are not evident in the central and eastern portions of the catchment. In these locations, the larger identified cycles have approximately 8 years, beginning in the decade of 1970 . 

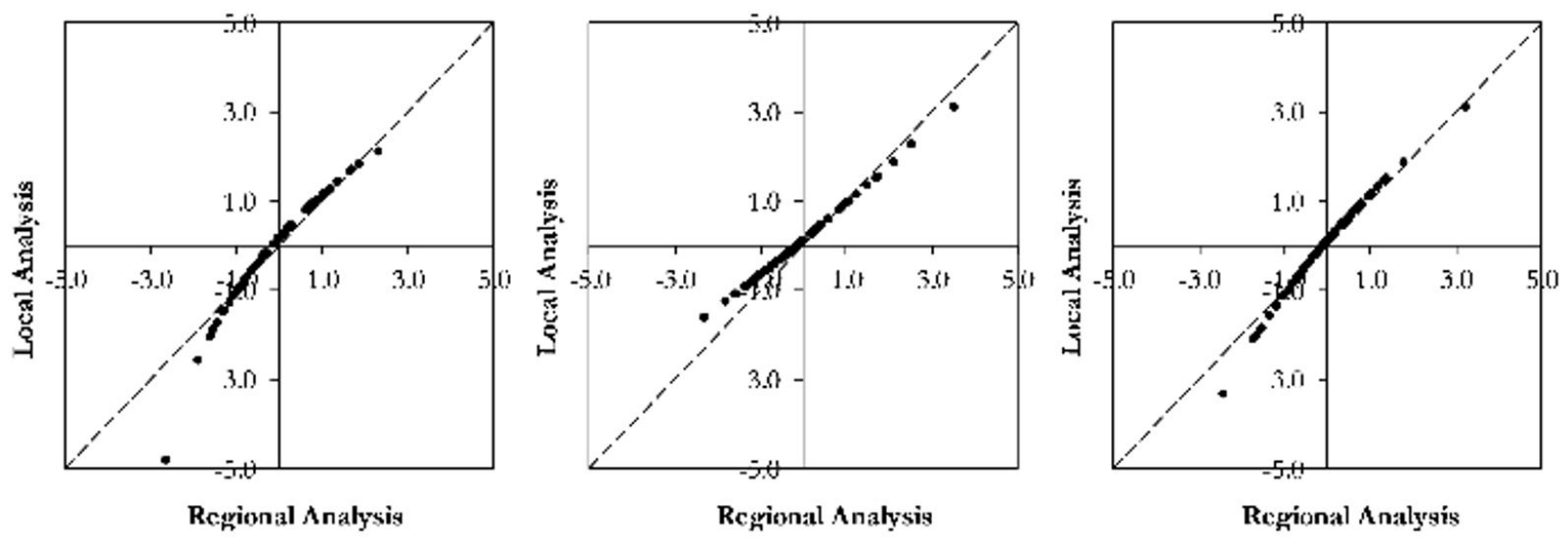

Figure 4. Scatterplot of SPI estimates obtained from local and regional analysis.
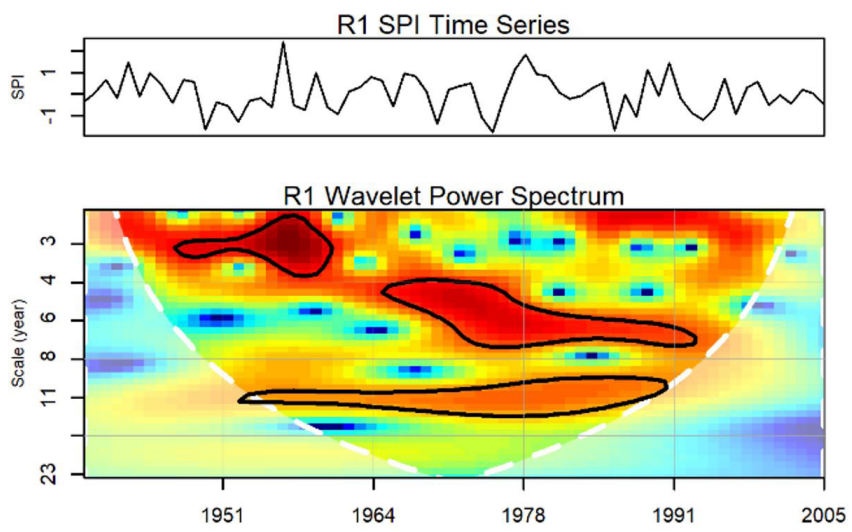

Figure 5. Wavelet analysis in region 01 . Warm colors denote high values of the power spectrum and cold colors denote low values. The black thick contours represent significant areas at the $5 \%$ significance level.

Finally, 2 to 4 -year cycles are frequent in almost all homogeneous regions. Nonetheless, these shorter cycles are irregularly distributed along the period-of-record. In turn, it is worth mentioning that most of the referred cycles were also identified by Vásquez et al. (2018) in São Paulo with the use of a discrete wavelet transform, which may suggest that these are representative of a larger area in the Brazilian southeastern region.

In spatial terms, it is possible to observe that in the mid-western portion of the study area, encompassing regions R3, R4 and R5, the referred intermittent short-term oscillations occur less frequently, suggesting that these areas are less prone to drought cycles. For regions R7 to R10, on the other hand, the opposite is verified: the intervals between short-term oscillations are relatively shorter, which may entail more frequent drought cycles. This fact may be further aggravated by the intensive demands of water for human consumption, irrigation and industrial use in this region, which may require very complex water systems and policies for dealing with the trade-off between exploitation of water resources and the higher frequency of drought events.

\section{Teleconnection patterns with ENSO and PDO}

Figure 7 presents the wavelet analysis of the ENSO time series from 1950 to 2006. Two frequencies, corresponding to the 4-year and the 16-year oscillation patterns, presented significant power spectrum, at the 5\% significance level. These two cycles prevail throughout almost all the period-of-record. The oscillation in the longer cycles is very evident in the analysis of this signal. This observation reinforces the point raised by Torrence and Compo (1998) that, in addition to the observed 4-year cycles, the ENSO phenomenon is also subject to modulations of approximately 15 years.

The PDO wavelet analysis, whose results are shown in Figure 8, for the period from 1930 to 2006, revealed a short cycle of approximately 6 years during the 1950's, and another cycle of about 32 years spanning from 1940 to 1965 . The latter, however, is located outside the cone of influence and therefore cannot be considered statistically significant. It may point out, however, to very low frequency patterns that may indicate a non-stationary behavior of the signal. From 1925 to 1946, the PDO was in the warm phase, whereas from 1947 to 1976, the index remained in the cool phase.

Figure 9 presents the squared WCO power contrasting the SPI and ENSO series. Here, the warm colors denote a high degree of linear correlation between cycles, whereas the cold colors mean otherwise. One may notice that, for the northern and central parts of the study area, the 16-year cycles are strongly correlated throughout most of the period-of-record. This is particularly evident in the 70's, which coincides with a cold phase of ENSO. For the southern portions, the referred cycle is remarkably weaker until de decade of 1990, and from this point on it becomes significant. We acknowledge that unreliable estimates of the power spectrum are likely to be obtained outside of the cone of influence. Nonetheless, there is evidence that the longer SPI cycles are conditioned by negative anomalies in ENSO. This is also supported by the findings of Awange, Mpelasoka and Gonçalves (2016), who employed a 112-year 12-month SPI time series for spectral analysis.

Other significant correlated yet intermittent cycles are observed for high frequencies, mainly between 2 and 4 years. These 


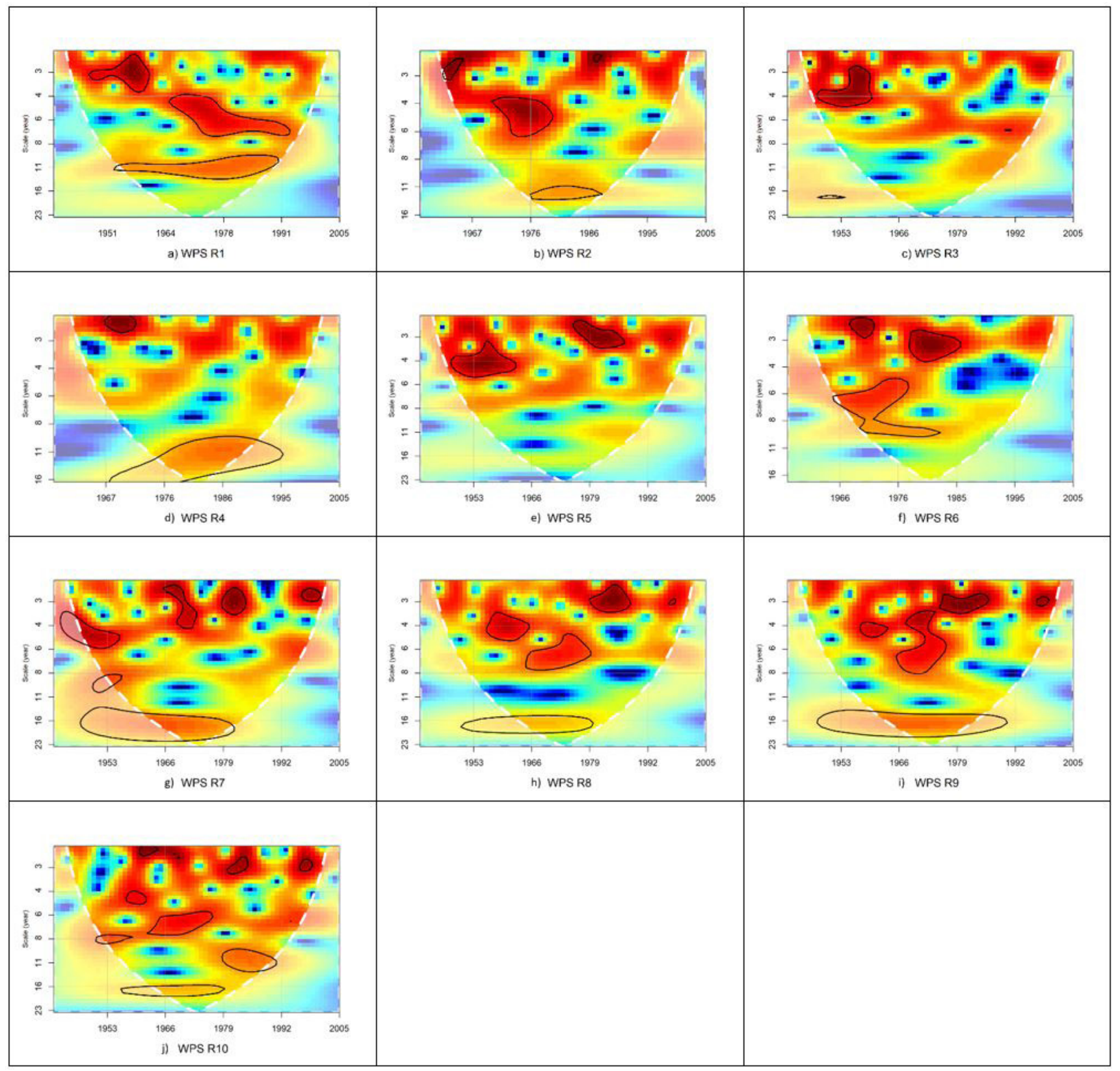

Figure 6. Wavelet spectra over homogeneous regions. Warm colors denote high values of the power spectrum and cold colors denote low values. The black thick contours represent significant areas at the $5 \%$ significance level.

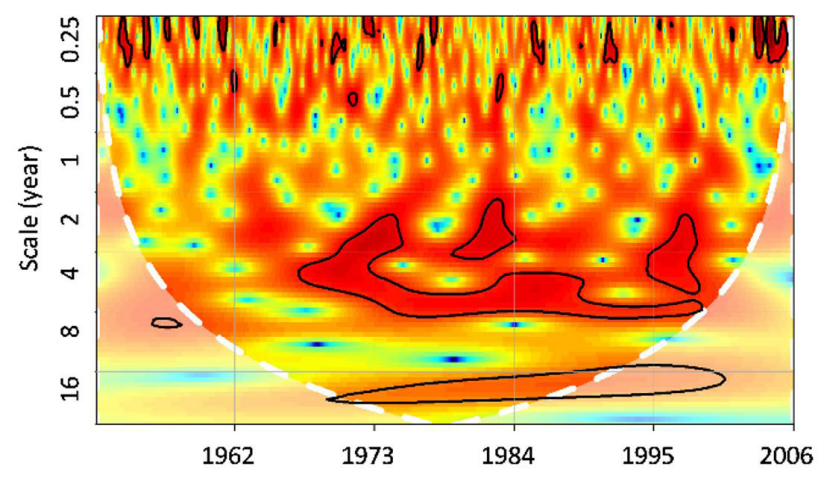

Figure 7. Wavelet Analysis applied to ENSO.

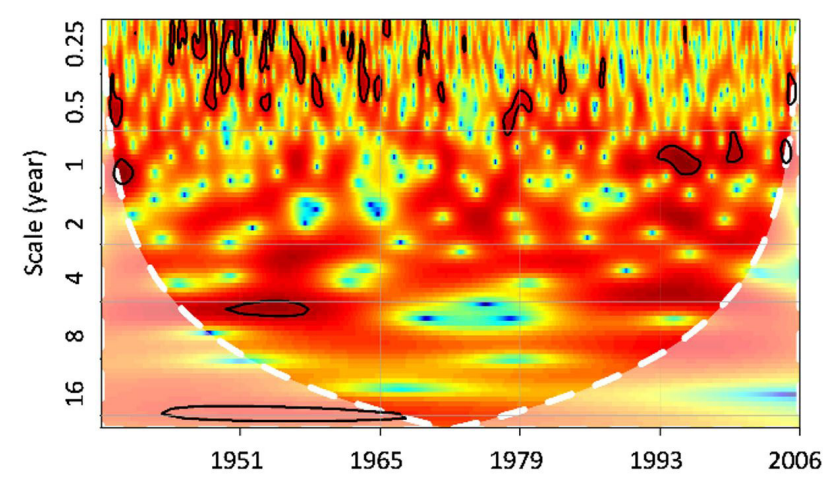

Figure 8. Wavelet Analysis applied to Pacific Decadal Oscillation. 


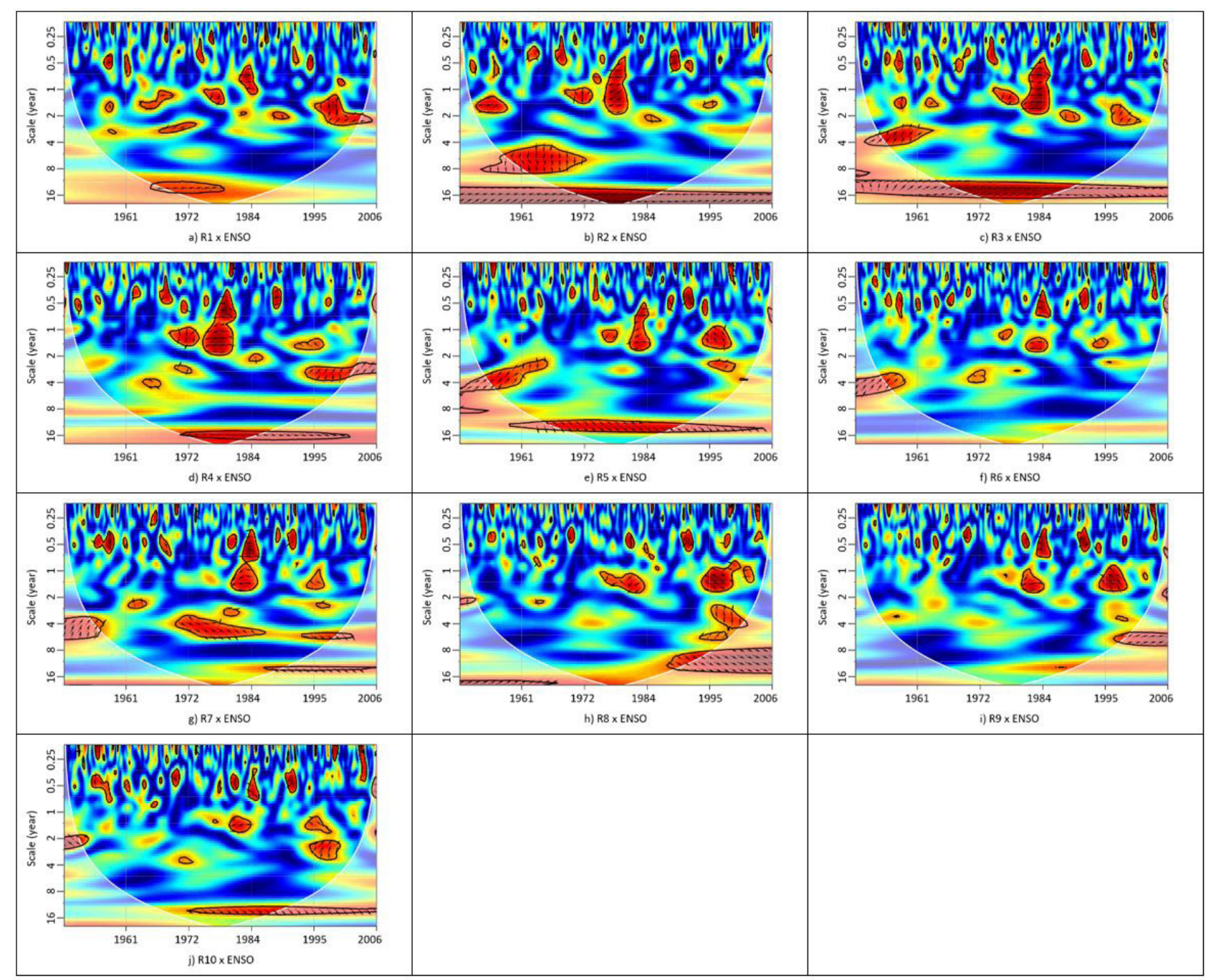

Figure 9. Wavelet coherence between SPI and ENSO over homogeneous regions. Warm colors denote a high degree of linear correlation between cycles and cold colors mean otherwise.

are often related to warm phases of ENSO. Again, the wavelet coherences appear to be stronger in the northern homogeneous regions. However, for these periodicities is not straightforward to distinguish spatial patterns. A similar condition was observed by Blain (2012) in rainfall gauging stations spread across the nearby Brazilian state of São Paulo.

When analyzing the coherence between SPI and PDO time series (not shown here), no persistent pattern of co-oscillation was revealed. Intermittent cycles spanning from 2 to 4 years were verified in regions R1, R3 and R4 until the early 90's, when they became significant in all regions. However, although a few coherent periods may be observed, no evident relationship between SPI and PDO could be found in the study area. This fact was somewhat expected since no periodic components were clearly identified for this climate index, at least for evaluated wavelets scales. Such a feature, however, may not hold for longer time series. In fact, Awange, Mpelasoka and Gonçalves (2016) demonstrated that there exists a significant negative correlation for the 12-month
SPI and PDO samples, which span more than a hundred years, in the Brazilian southeastern region.

For further exploring the influence of large-scale climate indexes in rainfall deficits in the São Francisco River catchment, we have tracked those years with most severe drought conditions, as materialized by SPI values lower than -2, and investigated the concomitant behavior of PDO and ENSO with respect to their normal conditions. This analysis provided some insights on the drought dynamics in the study area. In fact, it was possible to note that the cold phase PDO predominated in 15 of the 18 driest years. In nine of these years, the cold phase ENSO was coincident with cold phase PDO. This may suggest that droughts in the entire catchment are likely to be more intense when PDO and ENSO are simultaneously in their cold phase. Obviously, this is not the only factor that leads to the onset of droughts in the study area. Nonetheless, it may be expected that drought conditions could be aggravated when such a climate anomaly occurs. 
Time-space characterization of droughts in the São Francisco river catchment using the

Standard Precipitation Index and continuous wavelet transform

\section{CONCLUSIONS}

This paper presented a time-space characterization of drought conditions in the São Francisco River catchment, on the basis of wavelet analysis of 9-month SPI time series. In order to improve SPI estimation and its spatial variability, the procedures for regional analysis with L-moments, as recommended by Hosking and Wallis (1997), were employed for defining statistically homogeneous regions, which are described by a unique probabilistic model under the scale-invariance principle. The continuous wavelet transform was then utilized for extracting time-frequency information from the resulting SPI time series in a multiresolution framework and for investigating possible teleconnections of these signals with those obtained from samples of the large-scale climate indexes ENSO and PDO.

The use of regional frequency analysis with L-moments, in fact, resulted in improvements in the estimation of SPI time series. It was observed that, by aggregating regional information, more reliable estimates of low frequency rainfall amounts were obtained. This also holds, for most cases, for more accurate estimation of severe drought events. In addition, it is worth noting that most of the obtained dimensionless probability distributions, as selected by means L-moment ratio diagrams and Hosking and Wallis' goodness-of-fit measure, were heavy-tailed. This fact suggests that, at least for the study area, the Gama probability function, which is prescribed by McKee, Doesken and Kleist (1993) in the original SPI computation routine, is unable to provide appropriate fits to rainfall data, in several time scales. Most reliable estimation of the SPI index are of great interest to managers, as they can more precisely determine how extreme the drought situation is. Regional analysis also showed relationships between the sizes of the defined homogeneous regions and the precipitation regime. In fact, for those areas in which the mean annual rainfall was smaller, the identified homogeneous regions were significantly larger.

Spectral analysis revealed spatial distinctions between cycles across the defined homogeneous regions. In effect, dominant cycles of approximately 16 years were verified in almost all the study area, apart from its eastern portion. The short cycles, on the other hand, occurred on intermittent basis for all homogeneous regions. However, very different patterns of temporal evolution were visualized in each region, pointing to possibly distinct mechanisms governing short-term drought cycles. In addition, the southern portion of the study area, which is also the most urbanized and densely populated, appears to be more prone to higher frequency drought cycles. As a result, more specific strategies for drought risk assessment and protection may be required in this region.

The wavelet coherence analysis suggested that anomalies in ENSO, both in warm and cold phases, may be related to drought cycles. For lower frequency oscillations, such as those of approximately 16 years, significant correlations were observed for SPI time series and ENSO in its cold phase. On the other hand, for short-term cycles, spanning from 2 to 4 years, the correlation was significant for the ENSO warm phase. As for the PDO index, no clear joint variation structure with the 9-month SPI time series was identified. It should be noted, however, that it proved very hard to define clear periodicities of droughts over time, even when the effects of the teleconnections are accounted for. Such difficulties were nevertheless expected in the study area, as the Brazilian Southeast constitutes the natural path for most air masses acting in South America in their way to the Atlantic Ocean, which causes great complexity in atmospheric circulation and low predictability of the behavior of rainfall over time. In other words, although some influence of large-scale circulation is perceived, one may not establish a strict cause-effect relationship between droughts and the evaluated climate indexes.

A closer look at the joint behavior of the three time series suggests that the more extreme dry periods in the study area are observed when the cold phase of both ENSO and PDO coincides. It was possible to infer that the more extreme droughts are consistently observed in this situation. The combination of certain conditions, yet to be identified, with these climate indexes, both in their negative phases, is likely to induce more extreme droughts. However, further investigation is necessary for identifying particularities in rainfall patterns that are not associated to large-scale climate anomalies in order to obtain a more complete understanding of the drought dynamics in the São Francisco River catchment.

Finally, the proposed method is useful for identifying meteorological droughts, which, in the context of the study, is solely expressed by SPI values below -1 . Meteorological droughts are at the very genesis of other categories of drought and tracking the temporal evolution may reveal the predisposition of a given area to other drought typologies. Drought-related impacts, on the other hand, are just readily assessed for these other typologies, which depend on the mechanisms for drought propagation, mainly the catchment's storage conditions, and on the drought severity. Evaluating these impacts constitute a research avenue to be explored in future works.

\section{ACKNOWLEDGEMENTS}

The authors wish to thank the agencies FAPEMIG "Fundação de Amparo à Pesquisa do Estado de Minas Gerais", CAPES - Coordenação de Aperfeiçoamento de Pessoal de Nível Superior" and CNPq ("Conselho Nacional de Desenvolvimento Científico e Tecnológico") for their financial support to this research. The authors also wish to acknowledge the anonymous reviewers for the valuable comments and suggestions, which helped improving the paper.

\section{REFERENCES}

ABDOURAHAMANE, Z. S.; ACAR, R. Analysis of meteorological drought variability in Niger and its connections with climate indices. Hydrological Sciences Journal, v. 63, n. 8, p. 1203-1218, 2018. http:// dx.doi.org/10.1080/02626667.2018.1489542.

AWANGE, J.; MPELASOKA, F.; GONÇALVES, R. M. When every drop counts: analysis of droughts in Brazil for the 1901-2013 period. The Science of the Total Environment, v. 566-567, p. 1472-1488, 2016. http://dx.doi.org/10.1016/j.scitotenv.2016.06.031. PMid:27317137.

BARKER, L.; HANNAFORD, J.; CHIVERTON, A.; SVENSSON, C. From meteorological to hydrological drought using standardized indicators. Hydrology and Earth System Sciences, v. 20, n. 6, p. 2483-2505, 2016. http://dx.doi.org/10.5194/hess-20-2483-2016.

BLAIN, G. C. Monthly values of the standardized precipitation index in the State of São Paulo, Brazil: trends and spectral features 
under the normality assumption. Bragantia, v. 71, n. 1, p. 122-131, 2012. http://dx.doi.org/10.1590/S0006-87052012005000004.

BORGES, P. A.; BERNHOFER, C.; RODRIGUES, R. Extreme rainfall indices in Distrito Federal, Brazil: trends and links with El Niño southern oscillation and Madden-Julian oscillation. International Journal of Climatology, v. 38, n. 12, p. 4550-4567, 2018. http://dx.doi. org/10.1002/joc.5686.

COSTA, V.; FERNANDES, W. Bayesian estimation of extreme flood quantiles using a rainfall-runoff model and a stochastic daily rainfall generator. Journal of Hydrology, v. 554, p. 137-154, 2017. http://dx.doi.org/10.1016/j.jhydrol.2017.09.003.

CPC - CLIMATE PREDICTION CENTER. Climate WeatherLinkage: El Niño Southern Oscillation. 2019. Available from: < https://www. cpc.ncep.noaa.gov/products/precip/CWlink/MJO/enso.shtml>. Access on: 27 may 2019.

CUNHA, A. P. M. A.; TOMASELLA, J.; RIBEIRO-NETO, G. G.; BROWN, M.; GARCIA, S. R.; BRITO, S. B.; CARVALHO, M. A. Changes in the spatial-temporal patterns of droughts in the Brazilian Northeast. Atmospheric Science Letters, v. 19, n. 10, p. e355, 2018. http://dx.doi.org/10.1002/asl.855.

FERNANDES, L. G.; RODRIGUES, R. R. Changes in the patterns of extreme rainfall events in southern Brazil. International Journal of Climatology, v. 38, n. 3, p. 1337-1352, 2018. http://dx.doi. org/10.1002/joc.5248.

GOUHIER, T. C.; GRINSTED, A.; SIMKO, V. Conduct univariate and bivariate wavelet analyses. R Package, 2018. Available from: <https:// github.com/tgouhier/biwavelet>. Access on: 6 june 2018.

GRINSTED, A.; MOORE, J. C.; JEVREJEVA, S. Application of the cross wavelet transform and wavelet coherence to geophysical time series. Nonlinear Processes in Geophysics, v. 11, n. 5-6, p. 561-566, 2004. http://dx.doi.org/10.5194/npg-11-561-2004.

GUTTMAN, N. B. Comparing the palmer drought index and the standardized precipitation index. Journal of the American Water Resources Association, v. 34, n. 1, p. 113-121, 1998. http://dx.doi. org/10.1111/j.1752-1688.1998.tb05964.x.

HOSKING, J. R. M.; WALLIS, J. R. Regional frequency analysis: an approach based on L-moments. Cambridge: Cambridge University Press, 1997. 224 p. http://dx.doi.org/10.1017/CBO9780511529443.

HUANG, S.; LI, P.; HUANG, Q.; LENG, G.; HOU, B.; MA, L. The propagation from meteorological to hydrological drought and its potential influence factors. Journal of Hydrology, v. 547, p. 184-195, 2017. http://dx.doi.org/10.1016/j.jhydrol.2017.01.041.

JISAO-JOINT INSTITUTE FOR THE STUDY OF ATMOSPHERE AND OCEAN. PDO index. 2019. Available from: < http:// research. jisao.washington.edu/pdo/PDO.latest $>$. Access on: 27 may 2019.

KATZ, R. W.; PARLANGE, M. B.; NAVEAU, P. Statistics of extremes in hydrology. Advances in Water Resources, v. 25, n. 8-12, p. 1287-1304, 2002. http://dx.doi.org/10.1016/S0309-1708(02)00056-8.
KAYANO, M. T.; ANDREOLI, R. V. Decadal variability of northern northeast Brazil rainfall and its relation to tropical sea surface temperature and global sea level pressure anomalies. Journal of Geophysical Research, v. 109, n. C11, p. C11011, 2004. http://dx.doi. org/10.1029/2004JC002429.

LABAT, D. Recent advances in wavelet analyses. Part 1: a review of concepts. Journal of Hydrology, v. 314, n. 1-4, p. 275-288, 2005. http://dx.doi.org/10.1016/j.jhydrol.2005.04.003.

LABAT, D.; RONCHAIL, J.; GUYOT, J. L. Recent advances in Wavelet analyses, part 2-Amazon, Parana, Orinoco and Congo discharges time scale variability. Journal of Hidrology, v. 314, n. 1-4, p. 289-311, 2005. http://dx.doi.org/10.1016/j.jhydrol.2005.04.004.

LIMA, C. H. R.; AGHAKOUCHAK, A. Droughts in Amazonia: spatiotemporal variability, teleconnections, and seasonal predictions. Water Resources Research, v. 53, n. 12, p. 10824-10840, 2017. http:// dx.doi.org/10.1002/2016WR020086.

MARENGO, J. A.; TORRES, R. R.; ALVES, L. M. Drought in Northeast Brazil: past, present and future. Theoretical and Applied Climatology, v. 129, n. 3-4, p. 1189-1200, 2017. http://dx.doi. org/10.1007/s00704-016-1840-8.

MASSEI, N.; LAIGNEL, B.; DELOFFRE, J.; MESQUITA, J.; MOTELAY, A.; LAFITE, R.; DURAND, A. Long-term hydrological changes of the Seine River flow (France) and their relation to the North Atlantic Oscillation over the period 1950-2008. International Journal of Climatology, v. 30, n. 14, p. 2146-2154, 2010. http:/ /dx.doi. org/10.1002/joc. 2022 .

MASSEI, N.; LAIGNEL, B.; ROSERO, E.; MOTELAY-MASSEI, A.; DELOFFRE, J.; YANG, Z.-L.; ROSSI, A. A wavelet approach to the short-term to pluri-decennal variability of streamflow in the Mississippi river basin from 1934 to 1998. International Journal of Climatology, v. 31, n. 1, p. 31-43, 2009. http://dx.doi.org/10.1002/ joc. 1995.

MCKEE, T. B.; DOESKEN, N. J.; KLEIST, J. The relationship of drought frequency and duration to time scales. In: CONFERENCE ON APPLIED CLIMATOLOGY, 8., 1993, Anaheim. Anaheim: American Meteorological Society, 1993.

MISHRA, A. K.; SINGH, V. P. A review of drought concepts. Journal of Hydrology, v. 391, n. 1-2, p. 202-216, 2010. http://dx.doi. org/10.1016/j.jhydrol.2010.07.012.

MISHRA, A. K.; SINGH, V. P. Drought modeling: a review. Journal of Hydrology, v. 403, n. 1-2, p. 157-175, 2011. http://dx.doi. org/10.1016/j.jhydrol.2011.03.049.

MOREIRA, E. E.; MARTINS, D. S.; PEREIRA, L. S. Assessing drought cycles in SPI time series using a Fourier analysis. Natural Hazards and Earth System Sciences, v. 15, n. 3, p. 571-585, 2015. http:/ / dx.doi.org/10.5194/nhess-15-571-2015.

NAGHETTINI, M. C. Fundamentals of statistical bydrology. Cham: Springer International Publishing, 2017. 660 p. http://dx.doi. org/10.1007/978-3-319-43561-9. 
Time-space characterization of droughts in the São Francisco river catchment using the

Standard Precipitation Index and continuous wavelet transform

OLIVEIRA-JUNIOR, J. F.; GOIS, G.; TERASSI, P. M. B.; SILVA JUNIOR, C. A.; BLANCO, C. J. C.; SOBRAL, B. S.; GASPARINI, K. A. C. Drought severity based on the SPI index and its relations with ENSO and PDO climatic variability modes in the regions North and Northwest of the State of Rio de Janeiro - Brazil. Atmospheric Research, v. 212, p. 91-105, 2018. http://dx.doi.org/10.1016/j. atmosres.2018.04.022.

PALMER, W. C. Keeping track of crop moisture conditions, Nationwide: the new Crop Moisture Index. Weatherwise, v. 21, n. 4, p. 156-161, 1968. http://dx.doi.org/10.1080/00431672.1968.9932814.

PALMER, W. C. Meteorological drought. Washington: US Weather Bureau, 1965. 58 p. (Research Paper, 45).

PAPALEXIOU, S. M.; KOUTSOYIANNIS, D. A global survey on the seasonal variation of the marginal distribution of daily precipitation. Advances in Water Resources, v. 94, p. 131-145, 2016. http://dx.doi.org/10.1016/j.advwatres.2016.05.005.

PERCIVAL, D. P. On estimation of the wavelet variance. Biometrika, v. 82, n. 3, p. 619-631, 1995. http://dx.doi.org/10.1093/biomet/82.3.619.

SADRI, S.; BURN, D. H. A Fuzzy C-Means approach for regionalization using a bivariate homogeneity and discordance approach. Journal of Hydrology, v. 401, n. 3-4, p. 231-239, 2011. http://dx.doi.org/10.1016/j.jhydrol.2011.02.027.

SANTOS, J. F.; PULIDO-CALVO, I.; PORTELA, M. M. Spatial and temporal variability of drought in Portugal. Water Resources Research, v. 46, n. 3, p. W03503, 2010. http://dx.doi.org/10.1029/2009WR008071.

SAYERS, P. B.; YUANYUAN, L.; MONCRIEFF, C.; JIANQIANG, L.; TICKNER, D.; XIANGYU, X.; SPEED, R.; AIHUA, L.; GANG, L.; BING, Q.; YU, W.; PEGRAM, G. Drought risk management. a strategic approach. Paris: UNESCO, 2016.

SCHAEFLI, B.; MARAUN, D.; HOLSCHNEIDER, M. What drives high flow events in the Swiss Alps? Recent developments in wavelet spectral analysis and their application to hydrology. Advances in Water Resources, v. 30, n. 12, p. 2511-2525, 2007. http://dx.doi. org/10.1016/j.advwatres.2007.06.004.

SHAFER, B. A.; DEZMAN, L. E. Development of a Surface Water Supply Index (SWSI) to assess the severity of drought conditions in snowpack runoff areas. In: THE WESTERN SNOW CONFERENCE, 1982, Reno, Nevada. Proceedings... Fort Collins: Colorado State University, 1982. p. 164-175.

STRECK, N. A.; BURIOL, G. A.; HELDWEIN, A. B.; GABRIEL, L. F.; PAULA, G. M. Associação da variabilidade da precipitação pluvial em Santa Maria com a Oscilação Decadal do Pacífico. Pesquisa Agropecuária Brasileira, v. 44, n. 12, p. 1553-1561, 2009. http://dx.doi. org/10.1590/S0100-204X2009001200001.

TELESCA, L.; VICENTE-SERRANO, S. M.; LÓPEZ-MORENO, J. I. Power spectral characteristics of drought indices in the Ebro river basin at different temporal scales. Stochastic Environmental Research and Risk Assessment, v. 27, n. 5, p. 1155-1170, 2013. http://dx.doi. org/10.1007/s00477-012-0651-4.
TORRENCE, C.; COMPO, G. P. A practical guide to wavelet analysis. Bulletin of the American Meteorological Society, v. 79, n. 1, p. 6178, 1998. http://dx.doi.org/10.1175/1520-0477(1998)079<0061:AP GTWA>2.0.CO;2.

TORRENCE, C.; WEBSTER, P. J. Interdecadal changes in the ENSO-Monsoon system. Journal of Climate, v. 12, n. 8, p. 2679-2690, 1999. http://dx.doi.org/10.1175/1520-0442(1999)012<2679:IC ITEM>2.0.CO;2.

VAN HOEK, M.; JIA, L.; ZHOU, J.; ZHENG, C.; MENENTI, M. Early drought detection by spectral analysis of satellite time series of precipitation and Normalized Difference Vegetation Index (NVDI). Remote Sensing, v. 8, n. 5, p. 422-439, 2016. http://dx.doi. org/10.3390/rs8050422.

VAN LOON, A. F.; LAAHA, G. Hydrological drought severity explained by climate and catchment characteristics. Journal of Hydrology, v. 526, p. 3-14, 2015. http://dx.doi.org/10.1016/j.jhydrol.2014.10.059.

VÁSQUEZ, I. L.; ARAUJO, L. M. N.; MOLION, L. C. B.; ABDALAD, M. A.; MOREIRA, D. M.; SANCHEZ, A.; BARBOSA, H. A.; ROTUNNO FILHO, O. C. Historical analysis of interannual rainfall variability and trends in southeastern Brazil based on observational and remotely sensed data. Climate Dynamics, v. 50, n. 3-4, p. 801-824, 2018. http://dx.doi.org/10.1007/s00382-017-3642-9.

YANG, T.; XU, C.-Y.; SHAO, Q.; CHEN, X.; LU, G.-H.; HAO, Z.-C. Temporal and spatial patterns of low-flow changes in the Yellow River in the last half century. Stochastic Environmental Research and Risk Assessment, v. 24, n. 2, p. 297-309, 2009. http://dx.doi. org/10.1007/s00477-009-0318-y.

YEVJEVICH, V. An objective approach to definitions and investigations of continental hydrologic drought. Fort Collins: Colorado State University, 1967. (Hydrology Paper, 23).

ZELEKE, T. T.; GIORGI, F.; DIRO, G. T.; ZAITCHIK, B. F. Trend and periodicity of droughts over Ethiopia. International Journal of Climatology, v. 37, n. 13, p. 4733-4748, 2017. http://dx.doi. org/10.1002/joc.5122.

\section{Authors contributions}

Marcus Suassuna Santos: Conceptualization, methodology, data analysis, writing - original draft preparation.

Veber Afonso Figueiredo Costa: Methodology, data analysis, writing - original draft preparation, review and editing.

Wilson dos Santos Fernandes: Methodology, data analysis, writing - original draft preparation, review and editing.

Rafael Pedrollo de Paes: Data analysis, writing - review and editing. 